\title{
GENDER INEQUALITY REPRESENTED IN ENGLISH TEXTBOOKS: A LITERATURE REVIEW
}

\author{
Luh Shanti Nilayam Mihira ${ }^{1}$, Ni Komang Arie Suwastini ${ }^{*}$, Ni Nyoman Artini ${ }^{1}$, I Gusti Agung \\ Sri Rwa Jayantini², I Wayan Budiarta ${ }^{3}$ \\ ${ }^{1}$ Universitas Pendidikan Ganesha, Indonesia \\ ${ }^{2}$ Universitas Mahasaraswati Denpasar, Indonesia \\ ${ }^{3}$ Universitas Warmadewa, Indonesia \\ *e-mail: arie.suwastini@undiksha.ac.id
}

\begin{abstract}
Ideologies are contested through discourses; thus, textbooks can be a fertile ground for implanting the prevalence of women's marginalization in society, or they can also be used for deconstructing the ideology. The present study aims to provide a general map of how English as a foreign language reflects gendered stereotypes. The study was library research that used the results of previous studies to answer the research questions. Using George's method, the study chose thirty articles published in 2010 - 2021, then critically reviewed. The critical reading was continued with mapping the results of the studies, and their arguments on gender stereotypes included English as Foreign Language textbooks worldwide. The review revealed that there had been prevalent marginalization of women in English textbooks reflected through the depiction of women as less dominant, inferior than men, primarily domestic, generally weak, powerless, voiceless, and passive. Such male prevalence was also found in Indonesian EFL textbooks. Many previous studies admit that male prevalence and women marginalization in EFL textbooks reflect reality in society. Nevertheless, the present study takes the standpoint that calls for the utilization of textbooks to deconstruct gendered binary oppositions that marginalize women by deliberately designing textbooks that impart awareness about gender equity.
\end{abstract}

Keywords: Gendered Binary Oppositions; Male Prevalence; English as a Foreign Language Textbooks; Marginalization of Women

This is an open access article under the CC BY-SA license.

Copyright @ 2021 by Author. Published by Universitas Pendidikan Ganesha.

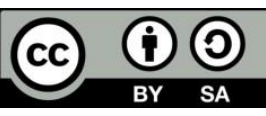

\section{INTRODUCTION}

Gender-biased treatments and the marginalization of women that they entail is one of the most persistent issues in society. The communication system delivers a code in the forms of sounds, sentences, and words that are affected by several factors, such as gender, culture, class, and race
(Aitchison \& Wardaugh, 1987). Cultural conditions and social stereotypes control gender roles in communication, as reflected in how men and women use language (Heilman, 2012; Mahmud, 2015; Phillips, 2005). Lakoff (1973) already highlights the difference in language use between men and women and how they are controlled by society 
and certain cultural values, resulting in language variations that either marginalize women or are internalized by women and further the marginalization (Coates, 2013; Sunderland, 2006). Women prevalently utilized powerless language, showing that language and gender were imparted in the social practice, achieving meaning through their activities (Eckert \& McConnell-Ginet, 2003). Women are disempowered by how they were taught to use particular language that later invokes the term women's language (Barr \& Atkins, 1980; Lakoff, 1973). Many dictions and sentence constructions in this women's language have been linguistically explained to create a demeaning effect on women. They maintain the false belief that women will never be in equal positions with men politically, professionally, socially, and culturally because women are weaker, less rational, and too emotional (Blangsinga et al., 2021; Faludi, 1992; Friedan, 1979; Gamble, 2014; Heilman, 2012; Millett, 2000; Suwastini, 2013; Tong, 2009). Beauvoir lamented this phenomenon as the system that forces female-born human beings to "become women" and occupy the second position in society (De Beauvoir, 1956).

Efforts have been made to eradicate the systematic marginalization of women. Early in the 18th Century, Mary Wollstonecraft called for a reform in the education system, pleading the equal access to education for girls, including access to subjects that were then considered masculine, such as algebra and calculus (Gamble, 2014;
Wollstonecraft, 1976). Since then, gradually, women gained more access to education, politics, and professions, only to be set back by systematic backlashes, highlighting the presence of the glass ceiling that systematically prevents women from advancing to top positions (Faludi, 1992). Jumping to the 21st Century, responding to the imbalance of gender equality across the globe, UNESCO (2012) has released a policy responding to systematic marginalization of women and negative gender stereotypes for women in the endeavors to decrease gender inequalities through education, including teaching material used in all types of education. It means textbooks and other reading material are supposed to raise awareness about gender equalities (Anggawati et al., 2018; Blangsinga et al., 2021; Dewi et al., 2018; Maheswari et al., 2020; Puspawati et al., 2021; Suwastini, Suprianti, et al., 2018; Suwastini, Utami, et al., 2018; Widasuari et al., 2020). Textbooks and what students read affect the students' perception toward gender equality and reflect the society's standpoint about the issue as represented by the texts as the product of the society (Al-Qatawneh \& $\mathrm{Al}$ Rawashdeh, 2019; Asadullah et al., 2018; Blangsinga et al., 2021; Gebregeorgis, 2016; Gharbavi \& Mousavi, 2012; Hameed, 2012; Rachmijati \& Cahyati, 2018; Setyono, 2018; Yonata et al., 2017). If girls and women are not equally represented in textbooks, they will internalize their invisibility in society (Taylor, 2003). Likewise, stereotyped characterizations of male and female characters in 
textbooks can contribute negatively to the internalizations of gender-biased femininity and masculinity. It could result in the foregrounding of women's marginalization in society, which can be internalized by the students (Blangsinga et al., 2021; Suwastini, Banjar, et al., 2020). Emilia, Moecharam, \& Syifa (2017), Islam \& Asadullah (2018), Julianti, Ikhsanudin, \& Y (2019), and Yang (2011) have expressed concerns that teachers sometimes unintentionally transfer gender-biased concepts into the classroom. They may do so through the language they use or the learning content. Teachers may lack time and awareness about gender equality to reflect on possible gender-biased content in the textbooks. According to Emilia et al. (2017), Islam \& Asadullah (2018), Julianti et al. (2019), and Yang (2011), such conditions significantly canceling the opportunity for schools to be the fertile ground for students to nurture students' awareness toward gender-biased stereotypes and women's marginalization. Textbooks should be one of the main arenas for teachers to unlearn the gender-biased stereotypes that they have internalized and for students to form politically correct perspectives about gender differences (Blangsinga et al., 2021; Gebregeorgis, 2016).

In the corroboratory spirit of evaluating the contribution of textbooks in the eradication, or at least the diminution, of gender-based stereotypes and its entailed marginalization, studies have been conducted on representations of gender issues in textbooks (Asadullah et al., 2018;
Bernabé-Villodre \& Martínez-Bello, 2018; Cobano-Delgado \& LlorentBedmar, 2019; Goyal \& Rose, 2020; Islam \& Asadullah, 2018; Parker et al., 2017). Such analyses are more pressing on language textbooks as language is a medium to transfer and transmit ideologies (Al-Qatawneh \& Al Rawashdeh, 2019; Blangsinga et al., 2021; Suwastini, Banjar, et al., 2020; Utami et al., 2020). English is the most learned foreign language globally (Dewi et al., 2018; Listiani et al., 2021; Purnamasari et al., 2016; Suwastini \& Yukti, 2017). The sheer number of students using English textbooks is both a threat and an opportunity for raising gender awareness (Bahman \& Rahimi, 2010; Blangsinga et al., 2021; Suwastini, 2013; Suwastini, Banjar, et al., 2020). EFL textbooks can be an invisible barrier and unconscious influence in education to equal gender as a reflection in societies (Ahmad \& Shah, 2019; Emilia et al., 2017). Gender biased-contents in English textbooks can affect students negatively, making students feel treated differently, intimidated, and losing their motivation to learn English (Julianti et al., 2019; Lee \& Mahmoudi-Gahrouei, 2020; Rachmijati \& Cahyati, 2018; Sari, 2011; Suhartono \& Kristina, 2018). Meanwhile, English material can adopt western culture and reflect the prejudices, values, and traditional culture that society has held (Emilia et al., 2017; Hayik, 2016; Lan \& Jingxia, 2019; Rachmijati \& Cahyati, 2018).

While many studies have traced efforts of raising gender awareness through English textbooks (Ariyanto, 
2018; Blumberg, 2008; Emilia et al., 2017; Hayik, 2016; Julianti et al., 2019; Lee, 2018; Nasrullah, 2016; Suhartono \& Kristina, 2018; Yonata et al., 2017) and deconstructions of gendered stereotypes in English textbooks (Blangsinga et al., 2021; Curaming \& Curaming, 2020; Gharbavi \& Mousavi, 2012; Lestariyana et al., 2020; Sari, 2011; Setyono, 2018; Yang, 2011; Yasin et al., 2012), yet the number of studies claiming otherwise is discerning. Thus, the present study aims to chart previous studies on gender representations in English textbooks to map the representations of gendered stereotypes and efforts to deconstruct them in those studies. The present study is expected to provide an elaborative and comprehensive summary of previous studies about gender representation in English textbooks, which can be informative for teachers and educators to trigger reflections on the content of the English textbooks that they use.

Furthermore, the mapping of previous studies' results in the present study can act as a preliminary study for further investigations of English textbooks and textbooks in general. It can provide general guidelines of what pointers should be paid attention to in terms of persistent gender-biased issues and the efforts to deconstruct them in previous studies.

\section{METHODS}

This study was designed as library research, following the model from George (2008). As a preliminary study, the present study was conducted qualitatively, following George's library research (2008) adaptation into a qualitative study by Ariantini et al. (2021). Figure 1 below illustrates the step-by-step procedures of the present study, along with the expected results from each step.
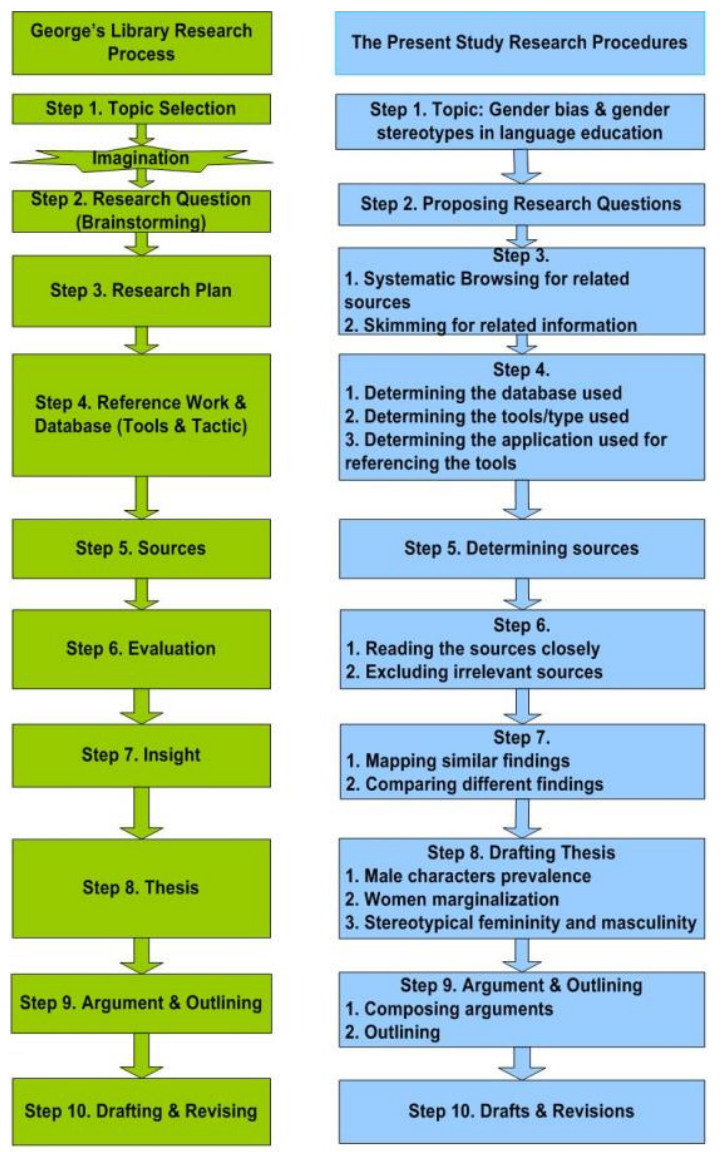

Figure 1. Research procedures adapted from George (2008) by Ariantini et al. (2021)

The first step was identifying the research topic. The researcher focused on the topic of gender bias and gender 
stereotypes that appeared in the educational field. The second step was designing research questions as the guide in this research, namely how men and women were represented in the English textbooks and what gender stereotypes are depicted in the English textbooks. The third step was to determine the research's plan by browsing, reading, and selecting the information related to websites, articles, and books and observing previous research analyzing EFL textbooks. The fourth step, deciding the sources of data; firstly, the database was selected as the resources, namely Google scholar, Taylor \& Francis (TANDFOLINE), and Science and Technology Index (SINTA). The data resources were determined by articles supported by relevant websites and Google scholar as the main website used to retrieve the articles. The articles were downloaded through an openaccess database due to the independent funding of the researcher.

The fifth step was determining the characterizations of the article used as this study's sources; the reviewed articles in this research were published in 2010-2021 in reputable international journals and accredited national journals accredited by Science and Technology Index (SINTA), indexed SINTA 1, SINTA 2, SINTA 3, and SINTA 4. Those articles were downloaded through an openaccess database with keywords; "gender stereotypes," "gender discrimination," "Gender Bias in English textbooks," "Inequality gender in education," "Gender inequality in EFL textbooks." Forty articles were retrieved and critically read in the sixth step. The limitation was set, in which only analyzing gender stereotypes which still exist in English textbooks. It was decided, this present study would be limited to the gender stereotype and inequality in English textbooks. After reducing the article, thirty articles were gained in representing the limitation of this study. Twenty articles were published in reputable international journals indexed by Scopus and/or Web of Sciences, 1 article was published in international conference proceedings indexed by Scopus. Two articles were published in international conference proceedings indexed by Web of Science articles were published in international journals indexed by Copernicus. In comparison, five articles were published in accredited national journals ranked Sinta 1, Sinta 2, Sinta 3, and Sinta 4.

The thirty articles were then critically read in the seventh step to understand how gender stereotypes or gender inequality were depicted in English textbooks in some countries. The information was summarized and written down in a tabulation classified into title, authors, years, background, theory, research question, and results. In step eight, the insights resulted from critical reading were used to propose the theses which answered the research question. Then, in the ninth step, the information was elaborated into several points based on the argument formation, answering the research questions before. Those points were represented in the form of the outline of the prevalence of male characters over female characters, marginalization of women in domestic roles, representation 
in activities, narrow range of occupational roles for women, the stereotypical characteristics of femininity and masculinity representations, and the deconstruction of gender stereotypes. The outline was then developed into the present article and revised accordingly, following the suggestion from colleagues and reviewers.

\section{RESULT AND DISCUSSION Prevalence Male Characters over Female characters}

A patriarchal society is, by definition, a society that privileges male interests over female ones (Gamble, 2014; Suwastini, 2013). This ideology can be reflected in discourses, including daily activities and spoken or written discourses. Articles reviewed in this study revealed the reproduction of patriarchal ideologies in English textbooks through the prevalence of male characters that marginalize women by limiting their participation, presence, visibility, and presentation. Figure 2 below summarizes the previous studies' arguments regarding the dismission of women over male dominance in English textbooks.

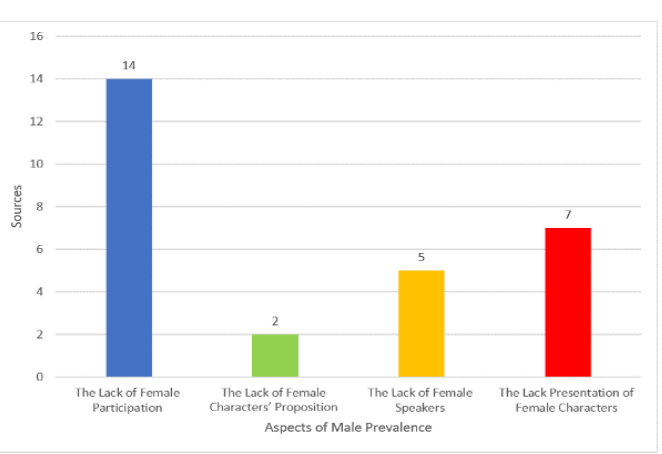

Figure 2. Male Prevalence
Imbalance representations in English storybooks were found and have been proven by previous studies, revealing that females are less dominant while men are more exclusively addressed to men in English textbooks. Studies have identified that English textbooks give their male characters more participation, sometimes with more important roles compared to participations allowed for female characters (Ariyanto, 2018; Barton \& Sakwa, 2012; Curaming \& Curaming, 2020; Emilia et al., 2017; Gharbavi \& Mousavi, 2012; Lee, 2019; Lee \& Mahmoudi-Gahrouei, 2020; Lestariyana et al., 2020; Paudel \& Khadka, 2019; Shamsuddin \& Hamid, 2017; Suhartono \& Kristina, 2018; Yonata et al., 2017). The male characters tend to monopolize the dominant participant in the form of higher education for occupation, outdoor activities, position in the societies, and hold the main characters in the stories (Ahmad \& Shah, 2019; Barton \& Sakwa, 2012; Blangsinga et al., 2021; Dabbagh, 2016; Emilia et al., 2017). Male characters frequently appeared in the EFL textbooks, strengthening men as the main characters (Ahmad \& Shah, 2019; Curaming \& Curaming, 2020; Damayanti, 2014; Gharbavi \& Mousavi, 2012; Lee, 2019). It was supported by the types of professional occupations that addressed male characters, such as judges, doctors, lawyers, scientists, CEO, police, manager, leader, engineer, photographers, and politicians (Ahmad \& Shah, 2019; Gebregeorgis, 2016; Lee \& Mahmoudi-Gahrouei, 2020; Paudel \& Khadka, 2019; Shamsuddin \& Hamid, 2017). Furthermore, women were given

Jurnal IImu Sosial dan Humaniora | 581 
the same professional occupations as men. Still, the predominance of men could be found through the senior post that revealing males overshadow female characters (Barton \& Sakwa, 2012).

Another dominance identified by these previous research is the more prevalent use of masculine pronouns compared to female ones, such as male titles, citation in indexes, figures, and the consistent use of masculine pronouns when referring to a noun or subject with unknown gender (Barton \& Sakwa, 2012; Blumberg, 2008; Lee \& Collins, 2010). The generic use of pronouns was frequently used in masculine nouns and masculine pronouns (Bahman \& Rahimi, 2010; Barton \& Sakwa, 2012; Damayanti, 2014; Yonata et al., 2017). The use of "Mr.," "chairman," "Businessman" was frequently used when the book tried to prefer people in general or unknown gender (Bahman \& Rahimi, 2010; Barton \& Sakwa, 2012). Additionally, the title of "Ms." was utilized commonly to address women, in which the term "Ms." was introduced as part of "Mr." It showed the evidence of gender bias and inequality that existed in the textbooks, revealing that the textbooks were dominated by male-related nouns and pronouns (Ahmad \& Shah, 2019; Lee, 2018; Yonata et al., 2017).

Lack of participation for female characters, when combined with lack of female pronouns, can contribute to the invisibility of the female characters (Barton \& Sakwa, 2012; Lee \& Collins, 2010). Such lack can create another implication on women' marginalization, where women's invisibility in the textbook diminishes women existence in the book, practically silencing them (Ahmad \& Shah, 2019; Ariyanto, 2018; Barton \& Sakwa, 2012; Blangsinga et al., 2021; Damayanti, 2014; Emilia et al., 2017; Lee \& Mahmoudi-Gahrouei, 2020). Lack of female speakers in the dialogues and reading texts included in the English textbooks is an endorsement of women's invisibility and silencing in the book (Ahmad \& Shah, 2019; Bahman \& Rahimi, 2010; Gharbavi \& Mousavi, 2012; Julianti et al., 2019; Paudel \& Khadka, 2019; Sari, 2011). Even though female characters are present in the English textbooks, Hameed (2012), Julianti et al. (2019), Paudel \& Khadka (2019), Sari (2011), and Yonata et al. (2017) notice that female speakers pose fewer speeches in dialogues and stories. Blangsinga et al. (2021), for example, noticed that the female characters in the narrative text included in the English textbook for grade 10 in Indonesia rarely speak. When they do speak, it is mainly when they express the need for help or favor or express submissions. Likewise, Abraham (2017) and Ariyanto (2018) identified that the female characters included in dialogues usually answer questions from the male characters instead of taking the active role of asking the questions. Abraham (2017) reveals that male characters usually dominate a story, as they are assigned as the main characters that continuously appear in the story.

The accumulated implication of the three forms of male dominance elaborated above is the underrepresentation of women in English textbooks (Abraham, 2017; Ariyanto, 
2018; Barton \& Sakwa, 2012; Emilia et al., 2017; Gharbavi \& Mousavi, 2012; Lee \& Mahmoudi-Gahrouei, 2020; Paudel \& Khadka, 2019). Gharbavi \& Mousavi (2012) argue that the lack of women representation in English textbooks may reflect the reluctance to depict female bodies. This argument seems closely related to religious and cultural beliefs that women's bodies are sacred (and thus not for show) or reflect profanity that lures men's desires. However, they also admit that textbooks' lack of female representations reflects the reluctance to place women as the center of attention. Thus, including fewer girls or women in the textbooks, assigning fewer female speakers, making the female characters more silent and passive seem to reflect the mainstream ideologies to exclude women from education and other dominant roles.

Predominant male characters over female characters were also found in English textbooks used in Indonesia. Studies have identified that English textbooks used in Indonesia show the dominance of male characters over female ones (Rachmijati \& Cahyati, 2018; Sari, 2011; Suhartono \& Kristina, 2018; Yonata et al., 2017). As a result, there emerged the possibility of creating gender-stereotyped and gender ideology to students as the reflection of Indonesian culture (Suhartono \& Kristina, 2018; Yonata et al., 2017). The main characters were primarily male, while the female characters were placed as the passive ones: they became the receiver of the action, the ones affected by the active characters, or they were simply the listeners to male's speech (Damayanti, 2014; Emilia et al., 2017). This dominance of male characters indicated in the English textbooks may reflect a twofold implication. The first is the possibility of the textbooks to reflect the marginalization of women in Indonesian society, where the society privileges men's interests while casting aside women as less consequential. The other side of the implication is the possibility of reproducing women's marginalization among school children by depicting male dominance in their English textbooks. Thus, the studies strongly call for more conscious efforts to represent more balanced gender equality in textbooks' materials to open more opportunities for female students, increasing their confidence to actively enroll themselves in the nation's development (Blangsinga et al., 2021; Sari, 2011).

\section{Marginalization of Women in Domestic Roles}

The higher representation of female characters in domestic roles is closely related to real societies' cultural values. The domestic setting has become the space to perform the stereotypical feminine role, such as nurturing, cooking, or taking care of children (Friedan, 1979; Millett, 2000). Previous research reviewed in this study reveals that English textbooks maintain the gendered stereotypes that assign domestic and passive roles to women. At the same time, men are given more active roles and outdoor settings. Table 1 below summarizes the genderedbiased activities assigned to female and 
male characters in the English textbooks observed in the previous studies.

Table 1. Activities based on Traditional Gender Stereotypes

\begin{tabular}{ll}
\hline Woman's Activities & Man's Activities \\
\hline Nurturing & Fishing \\
Cooking & Playing \\
Childrearing & Doing sports \\
Babysitting & Traveling \\
Cleaning the house & Climbing \\
Washing dishes & Running \\
\hline
\end{tabular}

It can be observed that female characters were identified to be depicted doing nurturing and domestic activities, such as cooking, childrearing, babysitting, cleaning, and washing dishes, while male characters were listed to be doing fishing, playing, doing sports, traveling, climbing and running (Barton \& Sakwa, 2012; Curaming \& Curaming, 2020; Dabbagh, 2016; Emilia et al., 2017; Gebregeorgis, 2016; Hameed, 2012; Hayik, 2016; Julianti et al., 2019; Lee, 2019; Lee \& MahmoudiGahrouei, 2020; Paudel \& Khadka, 2019; Setyono, 2018; Suhartono \& Kristina, 2018; Yonata et al., 2017). Furthermore, male characters were always depicted as actively taking the roles of lead participants of main course action, while women were depicted as passive and monotonous in their activities (Dabbagh, 2016; Hameed, 2012). Yasin et al. (2012) are particularly concerned with the image of girls in the action of "serving" food to boys in the English textbooks that they observe (Yasin et al., 2012). Gebregeorgis (2016) recognizes the ambiguous equal chance of boys and girls in EFL textbooks to engage in domestic and leisure activities. However, they had different types of activities. When at home, the female characters were depicted cooking, doing housework, fetching water, feeding hen, washing dishes, and cleaning the kitchen. On the other hand, the boys' activities were taking a rest, playing with friends which quite different compared to girls' activities, in which they even did not have time to rest.

Indonesian EFL textbooks are not an exception in showing the inequality of gender through English textbooks. Indonesian ELT textbooks tend to portray male characters as superior to female characters in the form of masculinity traits that showed their power, e.g., leadership, climbing, or doing sports. Those activities strengthened the stereotype that men needed to be strong, brave, powerful, adventurous, risk-taker, rational, and powerful (Ariyanto, 2018; Emilia et al., 2017; Suhartono \& Kristina, 2018). In contrast, cooking, nurturing, studying, cleaning, and preparing foods referred to female characters' feminine traits. Those kinds of activities are categorized as feminine traits, emphasizing the characterizations of nurturing women (Blangsinga et al., 2021). It was not only how women or female characters chose to be at home and doing home-care activities, but Damayanti (2014) also reported that English textbooks represented female characters as the goals, meaning that characters who always being affected by male characters. Male characters were

Jurnal IImu Sosial dan Humaniora | 584 
described as characters that did the activities independently; female characters were mostly related to social activities, meaning they always did everything with others and needed help. Most activities were stereotyped and contained the cultural values of Indonesian people, where the patriarchal system is dominant.

Patriarchal society assigns masculine activities for their male member, while feminine activities are assigned for the female members (Blangsinga et al., 2021; De Beauvoir, 1956; Faludi, 1992; Friedan, 1979; Gamble, 2014; Millett, 2000; Suwastini, 2013; Suwastini, Banjar, et al., 2020). Assigning domestic activities to women and placing female characters in domestic spaces in EFL textbooks may strengthen the traditional beliefs that women should stay at home and do domestic chores (Barton \& Sakwa, 2012; Curaming \& Curaming, 2020). Thus, the labor divisions displayed in Table 1 above reflect the binary oppositions Millet (2000) argued and proven by Blangsinga (2021), where traditionally, women are dominantly associated with domestic and feminine activities, and men are assigned outdoor and masculine activities.

\section{Narrow Range of Occupational Roles for Women}

One of the awareness raised by feminist movements is the equal opportunities for career advancement and eliminating the "glass ceiling" that has been persistently limiting women in the workplace (Faludi, 1992; Friedan, 1979). This awareness should be conducted informal and informal contexts, especially among students (Anggawati et al., 2018; Blangsinga et al., 2021; Suwastini, Banjar, et al., 2020). Textbooks, as an integral part of education, should also promote gender equality in terms of occupations. However, studies have identified the persistence of a limited range of occupations assigned for women, along with gendered stereotypes of what occupations are suitable for women and what professions are normatively assigned for men. Table 2 below displays the divisions of occupations between men and women, where men are assigned with more varied occupations than women, and the type of occupations assigned to men are generally more masculine than the feminine types of jobs assigned to women.

Table 2. Gender Occupational Division

\begin{tabular}{ll}
\hline Woman's Occupation & Man's Occupation \\
\hline Driver & Reporter \\
Salesgirl & Police \\
Teacher & Doctor \\
Mother & Photographer \\
Wife & Judge \\
Nurse & Manager \\
Waitress & Leader \\
Housemakers & CEO \\
& Engineer \\
& Lawyer \\
& Scientist \\
& Politician \\
& Soldier \\
\hline
\end{tabular}

The majority of the books observed by previous research reviewed in this study represent women having fewer occupational choices than men. 
And then, the occupations assigned for men are equivocally typical to the traditional roles of women as housemaker and caretaker, while men were assigned with a professional occupation that required a higher educational level (Barton \& Sakwa, 2012; Emilia et al., 2017; Gebregeorgis, 2016; Gharbavi \& Mousavi, 2012; Julianti et al., 2019; Lee, 2019; Lee \& Mahmoudi-Gahrouei, 2020; Paudel \& Khadka, 2019; Sulaimani, 2017; Yang, 2016). Barton \& Sakwa (2012), Goyal \& Rose (2020), Julianti et al. (2019), Paudel \& Khadka (2019) recognize that EFL textbooks assigned men with professions of the public sphere, well-paid and high-status jobs, such as a doctor, judge, manager, leader, CEO, engineer, photographer, lawyer, scientist, politician. Additionally, men's occupation was frequently related to their power and physical demands, e.g., police and soldier (Lee, 2019). It represented that male characters will be a center when the story came to crime, success stories, solid national identity, politicians, and government (Lee \& Collins, 2010). On the other hand, female characters in the EFL textbooks analyzed by the studies observed in the present review primarily assigned their female characters with domestic and feminine occupational roles, such as wife, mother, teachers, or nurse were mainly imparted to female characters (Julianti et al., 2019; Lee, 2019; Lee \& Collins, 2010; Shamsuddin \& Hamid, 2017). These professions are closely linked to their traditional "natural" space as women and mothers, the home (Gamble, 2014; Lee, 2019; Shamsuddin \& Hamid, 2017). Besides, prestigious jobs, such as reporters, police, doctors for male characters, were illustrated to confined their role as "man" and gave low prestigious jobs; driver, waitress, and salesgirl to female characters (Paudel \& Khadka, 2019; Sulaimani, 2017).

Research on Indonesian EFL textbooks also reveals similar gendered occupational roles between the male and female characters included in the textbooks. Suhartono \& Kristina (2018) argue that English textbooks used in Indonesian schools illustrated the male characters as successful men with strong leadership, while the female characters were given more inferior professions and weaker leadership. Emilia et al. (2017), Lestariyana et al. (2020), and Setyono (2018) notice that Indonesian EFL textbooks included female characters who do domestic activities, such as caring for children, cooking, doing laundry, cleaning, ironing, and doing groceries. Setyono (2018) recognizes the effort to deconstruct the biased concept that women should not work professionally or pursue their careers by including career-women in Indonesian English textbooks. However, he was disappointed that the career women were also depicted to do domestic chores, which directly represents what Faludi calls "the feminists' double burden."

Lestariyana et al. (2020), Rachmijati \& Cahyati (2018), and Setyono (2018) are concerned that the limited range of occupations assigned to female characters in the EFL textbooks will be internalized by the female 
students as the only accepted occupations for them to pursue. Moreover, they are apprehensive that the assignment of nurturing, caring, and serving chores for female characters would be read by the female students as the roles that define them as women, without which they may consider themselves inadequate or unacceptable. Emilia et al. (2017) and Suhartono \& Kristina (2018) point their concern to another corner. They saw that assigning masculine and decisive occupations requiring strong leadership and high salaries in EFL textbooks would negatively affect male students' perceptions of what society expects from men. Considering that traditionally male descendent become the heirs of the family's fortune and the providers for their female family members, the assignment of well-paid occupations of male characters may emphasize the traditional expectations of men as the breadwinner of the family.

\section{Stereotypical Femininity and Masculinity}

Millet (2000) most fervently notices how men and women are characterized with opposing traits that always marginalize women. They end up being the lesser human being, second to men as the unmarked sex (De Beauvoir, 1956). Previous research observed in the present study identified the persistence of these gendered binary oppositions, where the female characters are assigned with the typical feminine traits, and the male characters are assigned with typical masculine traits. Table 3 below summarized these opposing pairings as summarized from the previous studies observed in the present study.

Table 3. Stereotypical Characteristics based on Femininity and Masculinity Traits

\begin{tabular}{ll}
\hline Femininity Trait & Masculinity Trait \\
\hline Shy & Brave \\
Weak & Strong \\
Passive & Rude \\
Kind & Wise \\
Expressive & Ambiguous \\
Empathetic & Hard-working \\
Submissive & Controlling \\
Powerless & Powerful \\
Dependent & Independent \\
Emotional & Rational \\
Reluctant & Bold \\
Fashionable & Formal \\
Clothes & \\
Neatly dressed & Casual Outfits \\
Long-haired & Short-haired \\
Soft or Bright & Dark-colored \\
Colored outfits & outfits \\
listeners & speakers \\
Traditional & Progressive \\
\hline &
\end{tabular}

Table 3 displays the characterizations given to female characters in EFL textbooks around the world: shy, weak, passive, kind, expressive, empathetic, submissive, powerless, dependent, emotional, reluctant, traditional, neatly dressed in fashionable clothes, or modestly dressed in traditional or religious clothing, long-haired, and generally good listeners (Ariyanto, 2018; Barton \& Sakwa, 2012; Blangsinga et al., 2021; Hameed, 2012; Julianti et al., 2019; Lan \& Jingxia, 2019; Lee, 2018; Lee \& Mahmoudi-Gahrouei, 2020; Paudel \& Khadka, 2019; Setyono, 2018;

Jurnal IImu Sosial dan Humaniora | 587 
Suhartono \& Kristina, 2018; Yang, 2016). From these characterizations, women are generally depicted as the passive sex who are either religious or vain. Religious women are presented in modest clothing in dull-colors clothing (Lee \& Mahmoudi-Gahrouei, 2020), while the vain women seem to concern themselves more with how they look with their either bright or soft-colored clothing and long, well-arranged, and neatly accessorized hairs (Setyono, 2018; Yang, 2016). Paudel \& Khadka (2019) are apprehensive that the EFL textbooks they observed persistently presented women as passive listeners who waited for men to initiate conversations. For them, internalizations of this passivity can further silence women's voices so often found in society. Bahman \& Rahimi (2010), Julianti et al. (2019), Lan \& Jingxia (2019), Lee \& Collins (2010), and Suhartono \& Kristina (2018) are concerned that the assignment of shy, passive, weak, dependent, powerless, and submissive traits on the female characters included in EFL textbooks will confirm the traditional beliefs about the inferiority of the female sex. They are anxious that students will internalize them as the expected traits among girls. Brody (2001) argues that the descriptions of female characters in textbooks as emotional, weak, and passive may reflect women's characters in real life. Nevertheless, Blangsinga et al. (2021) are adamant that textbooks should seek to deconstruct the normative attribution of stereotypically feminine traits to women. They argue that textbooks and educations should be part of the deliberate effort to break the hierarchical dichotomy that limits girls to certain sets of traits to be accepted as standard female members of the society. For Blangsinga et al. (2021), negative gender constructions normalized in society should not be part of the characterizations in EFL textbooks.

From Table 3 , it can also be observed that male characters are generally depicted as brave, strong, rude, wise, ambiguous, hard-working, controlling, powerful, independent, rational, and bold, dark-colored formal outfits while at ease in their casual outfits, short-haired, progressive (Ariyanto, 2018; Barton \& Sakwa, 2012; Hameed, 2012; Julianti et al., 2019; Lee, 2018; Paudel \& Khadka, 2019; Suhartono \& Kristina, 2018). In general, EFL textbooks have been found to present their male characters as masculine, practical, and forwardthinking. Lee \& Mahmoudi-Gahrouei (2020), Paudel \& Khadka (2019), and Yang (2016) notice that men are predominantly depicted as short-haired with dark-colored outfits that shows their masculinity and the absence of assiduous fashions prevalent among their female counterparts. Bahman \& Rahimi (2010), Blangsinga et al. (2021), Julianti et al. (2019), Lee \& Collins (2010), Suhartono \& Kristina (2018) highlight the prevalence of toxic masculinity where men are depicted as masculine, independent, strong, powerful heroes who are at command with their life. Julianti et al. (2019) are especially wary of the depiction of this masculine emphasis in male characters 
because it strengthens the taboo that "a boy does not cry," which, for Juliani et al. (2019), is not natural.

The gendered binary oppositions in the characterizations of male and female characters included in EFL textbooks also persist in the textbooks mandatorily used in Indonesian EFL classrooms. Male characters were depicted to have positive personalities, such as nationalism, full of spirit, skills, hard workers, expressive, active, and good ability in some subjects, such as math and science (Ariyanto, 2018; Suhartono \& Kristina, 2018). Blangsinga et al. (2021) and Damayanti (2014) recognize the persistence of strong, diligent, ambiguous, hard worker, brave, independent, rational, healthy, and physically strong males in the Indonesian EFL textbooks, where the female characters are depicted as generally beautiful, weak, passive, and diligent, with only the honest ones get rewarded, while the cheating ones are severely punished. Sari (2011) is concerned that the female characters' involvement through passive voice clauses and the male character's involvement through active voice strengthens the message that the male characters were the active, independent, and capable gender. Rachmijati \& Cahyati (2018) admit that some of the characterizations do depict the reality of how men, boys, women, and girls look and behave in Indonesia. However, to include these in a textbook would impart students with the systematic binary divisions that burden and limit both men and women (Julianti et al., 2019) but more so for women
(Blangsinga et al., 2021; Damayanti, 2014). As Harashima (2005) argues, gender stereotypes in textbooks will significantly promote insensitivity the lack of awareness to the equality between women and men in societies (Harashima, 2005).

\section{CONCLUSIONS RECOMMENDATIONS}

AND

The critical review conducted in the present study revealed that most English textbooks reflected imbalance representation and gender-stereotyped toward female characters in the form of the domination of male characters, marginalization of women in domestic roles, a narrow range of occupational roles for women, and stereotypical characteristics of femininity and masculinity. It was evident that English textbooks presented discrimination and inequality towards women and some unrealistic expectations toward men. Researchers have shown concerns that the representations of gendered binary oppositions and the persistence of male dominance in EFL textbooks across the globe will impart and strengthen the gendered stereotypes. Teachers and students use textbooks as the material resources and the foundation in doing learning activities. Thus, the inclusion of biased gender matrices and marginalization of women in textbooks may result in internalizations of the gender-biased labor divisions, expectations toward how men/boys and women' girls should behave, and what they can or cannot do to be considered normatively acceptable in the society. Since depictions of attributions, labor 
and space divisions, and stereotypical characteristics between men/boys and women/girls reflect the systematic marginalization toward women in the society, their representations into EFL textbooks will strengthen this marginalization. Following suggestions from previous EFL textbooks reviewed in the present study, it is strongly suggested that EFL textbooks and textbooks, in general, should be written with an awareness of biased gender constructions and deliberate efforts to deconstructs these biased constructions.

\section{REFERENCES}

Abraham, I. (2017). Struktur kepribadian tokoh dalam novel Surat Kecil Untuk Tuhan karya Agnes Davonar. KEMBARA: Jurnal Keilmuan Bahasa, Sastra, Dan Pengajarannya, 3(1), 55-63. https://doi.org/https://doi.org/10.22 219/kembara.v3i1.4378

Ahmad, M., \& Shah, S. K. (2019). A critical discourse analysis of gender representations in the content of 5th grade English language textbook. International and Multidisciplinary Journal of Social Sciences, $8(1), \quad 1-24$. https://doi.org/10.17583/rimcis.201 9.3989

Aitchison, J., \& Wardaugh, R. (1987). An introduction to Sociolinguistics. In The British Journal of Sociology (Vol. 38, Issue 3). https://doi.org/10.2307/590702

Al-Qatawneh, S., \& Al Rawashdeh, A. (2019). Gender representation in the Arabic language textbook for the ninth grade approved by the Ministry of Education for use in schools in the United Arab Emirates (UAE). Studies in Educational Evaluation, 60(November 2018), 90-98. https://doi.org/10.1016/j.stueduc.2 018.12 .001

Anggawati, L. S., Suwastini, N. K. A., \& Mahayanti, N. W. S. (2018). Women's characterization in Mary Shelley's Frankenstein. In M. H. Santosa, I. M. S. Paramarta, N. L. P. S. Adnyani, \& I. G. A. L. P. Utami (Eds.), The Fourth International Conference on English Across Cultures (pp. 14-23). Undiksha Press.

Ariantini, K. P., Suwastini, N. K. A., Adnyani, N. L. P. S., Dantes, G. R., \& Jayantini, I. G. A. S. R. (2021). Integrating social media into English language learning: How and to what benefits according to recent studies. NOBEL: Journal of Literature and Language Teaching, 12(1), 91-111. https://doi.org/https://doi.org/10.15 642/NOBEL.2021.12.1.91-111

Ariyanto, S. (2018). A portrait of gender bias in the prescribed Indonesian ELT textbook for junior high school students. Sexuality and Culture, 22(4), 1054-1076. https://doi.org/10.1007/s12119018-9512-8

Asadullah, M. N., Islam, K. M. M., \& Wahhaj, Z. (2018). Gender bias in Bangladeshi school textbooks: Not just a matter of politics or growing influence of Islamists. Review of Faith and International Affairs,

Jurnal IImu Sosial dan Humaniora | 590 
16(2), $84-89$. https://doi.org/10.1080/15570274. 2018.1469821

Bahman, M., \& Rahimi, A. (2010). Gender representation in EFL materials: An analysis of English textbooks of Iranian high schools. Procedia - Social and Behavioral Sciences, 9, 273-277. https://doi.org/10.1016/j.sbspro.20 10.12.149

Barr, W. M. O., \& Atkins, B. K. (1980). Women's language or powerless language. In McConnell-Ginet, Borker, and Furman (pp. 93-110).

Barton, A., \& Sakwa, L. N. (2012). The representation of gender in English textbooks in Uganda. Pedagogy, Culture and Society, 20(2), 173190.

https://doi.org/10.1080/14681366. 2012.669394

Bernabé-Villodre, M. del M., \& MartínezBello, V. E. (2018). Analysis of gender, age and disability representation in music education textbooks: A research update. International Journal of Music Education, 36(4), 494-508. https://doi.org/10.1177/025576141 8763900

Blangsinga, G. W. K. A. A., Suwastini, N. K. A., Lasmawan, I. W., Adnyani, N. L. P. S., \& Rusnalasari, Z. D. (2021). Patriarchal binary oppositions in narrative texts included in English textbook for senior high school in Indonesia. 2nd International Conference on Technology and Educational Science (ICTES 2020), 135-141. https://doi.org/https://dx.doi.org/10. 2991/assehr.k.210407.227

Blumberg, R. L. (2008). The invisible obstacle to educational equality: Gender bias in textbooks. Prospects, 38(3), 345-361. https://doi.org/10.1007/s11125009-9086-1

Brody, L. (2001). Gender, emotion, and the family. Harvard University Press.

Coates, J. (2013). Women, men, and language (G. Leech \& M. Short (eds.); 3rd edition). Routledge.

Cobano-Delgado, V. C., \& LlorentBedmar, V. (2019). Identity and gender in childhood. Representation of Moroccan women in textbooks. Women's Studies International Forum, 74(November 2018), 137-142. https://doi.org/10.1016/j.wsif.2019. 03.011

Curaming, E. M., \& Curaming, R. A. (2020). Gender (In)equality in English textbooks in the Philippines: A critical discourse analysis. Sexuality and Culture, 24(4), 1167-1188. https://doi.org/10.1007/s12119020-09750-4

Dabbagh, A. (2016). Gender representation under critical image analysis: The case of Iranian ELT textbooks. International Journal of English Language \& Translation Studies, 4(4), 39-52.

Damayanti, I. L. (2014). Gender construction in visual images in textbooks for primary school students. Indonesian Journal of Applied Linguistics, 3(2), 100-116. https://doi.org/10.17509/ijal.v3i2.2 
72

De Beauvoir, S. (1956). The Second Sex. Jonathan Cape.

Dewi, A. A. M. I., Marhaeni, A. A. I. N., \& Suwastini, N. K. A. (2018). The Effect of Graphic Organizer upon Reading Comprehension of the Twelfth Grade Students of SMAN 1 Sukawati in Academic Year 2015/2016. Lingua Scientia, 23(1), 64.

https://doi.org/10.23887/ls.v23i1.1 6069

Eckert, P., \& McConnell-Ginet, S. (2003). Language and Gender. In Cambridge. Cambridge University Press.

https://doi.org/10.1017/CBO97811 07415324.004

Emilia, E., Moecharam, N. Y., \& Syifa, I. L. (2017). Gender in EFL classroom: Transitivity analysis in English textbook for Indonesian students. Indonesian Journal of Applied Linguistics, 7(1), 206-214. https://doi.org/10.17509/ijal.v7i1.6 877

Faludi, S. (1992). Backlash: The Undeclared War Against Women. Crown Publishing Group.

Friedan, B. (1979). The Feminine Mistique. In Most. Dell Publishing Co., INC.

Gamble, S. (2014). The Routledge Companion to Feminism and Postfeminism. In The Routledge Companion to Hermeneutics. https://doi.org/10.4324/978131577 1854

Gebregeorgis, M. Y. (2016). Gender Construction Through Textbooks: The Case of an Ethiopian Primary
School English Textbook. Africa Education Review, 13(3-4), 119140.

https://doi.org/10.1080/18146627.

2016.1224579

George, M. W. (2008). The elements of library research: What every student needs to know. Princeton University Press.

Gharbavi, A., \& Mousavi, S. A. (2012). A Content Analysis of Textbooks: Investigating Gender Bias as a Social Prominence in Iranian High School English Textbooks. English Linguistics Research, 1(1). https://doi.org/10.5430/elr.v1n1p42

Goyal, R., \& Rose, H. (2020). Stilettoed Damsels in Distress: the (un)changing depictions of gender in a business English textbook. Linguistics and Education, 58, 100820.

https://doi.org/10.1016/j.linged.202 0.100820

Hameed, A. (2012). A Gender-Based Study of English Textbooks Produced By Punjab Textbook Board and Oxford University Press for Elementary Level (Vol. 5, Issue 11) [Dura Space]. http://173.208.131.244:9060/xmlui/ handle/123456789/3588

Harashima, H. D. (2005). Sexual bias in an EFL Textbook: A case study. JALT2004 Conference Proceedings, 934-939.

Hayik, R. (2016). What Does This Story Say about Females?: Challenging Gender-Biased Texts in the English-Language Classroom. Journal of Adolescent and Adult Literacy, 59(4), 409-419.

Jurnal IImu Sosial dan Humaniora | 592 
https://doi.org/10.1002/jaal.468

Heilman, M. E. (2012). Gender stereotypes and workplace bias. Research in Organizational Behavior, 32, 113-135. https://doi.org/10.1016/j.riob.2012. 11.003

Islam, K. M. M., \& Asadullah, M. N. (2018). Gender stereotypes and education: A comparative content analysis of Malaysian, Indonesian, Pakistani and Bangladeshi school textbooks. PLOS ONE, 13(1), 1-24. https://doi.org/10.1371/journal.pon e. 0190807

Julianti, L., Ikhsanudin, I., \& Y, Y. G. S. (2019). A Content Analysis of Gender Bias in When English Rings A Bell Textbooks. International Journal of Learning and Instruction (IJLI), 1(1), 23. https://doi.org/10.26418/ijli.v1i1.33 401

Lakoff, R. (1973). Language and Woman's Place. Language in Society, 2(1), 45-80. https://doi.org/10.2307/4166707

Lan, T., \& Jingxia, L. (2019). On the Gender Discrimination in English. Advances in Language and Literary Studies, 10 (3), 155. https://doi.org/10.7575/aiac.alls.v.1 0n.3p.155

Lee, J. F. K. (2018). Gender representation in Japanese EFL textbooks-a corpus study. Gender and Education, 30(3), 379-395. https://doi.org/10.1080/09540253. 2016.1214690

Lee, J. F. K. (2019). In the pursuit of a gender-equal society: do Japanese EFL textbooks play a role? Journal of Gender Studies, 28(2), 204-217. https://doi.org/10.1080/09589236. 2018.1423956

Lee, J. F. K., \& Collins, P. (2010). Construction of gender: A comparison of Australian and Hong Kong English language textbooks. Journal of Gender Studies, 19(2), 121-137.

https://doi.org/10.1080/095892310 03695856

Lee, J. F. K., \& Mahmoudi-Gahrouei, V. (2020). Gender Representation in Instructional Materials: A Study of Iranian English Language Textbooks and Teachers' Voices. Sexuality and Culture, 24(4), 11071127.

https://doi.org/10.1007/s12119020-09747-z

Lestariyana, R. P. D., Widodo, H. P., \& Sulistiyo, U. (2020). Female Representation in GovernmentMandated English Language Textbooks Used in Indonesian Junior High Schools. Sexuality and Culture, 24(4), 1150-1166. https://doi.org/10.1007/s12119020-09752-2

Listiani, N. K. M., Suwastini, N. K. A., Dantes, G. R., Adnyani, N. L. P. S., \& Jayantini, I. G. A. S. R. (2021). YouTube as digital learning resources for teaching bilingual young learners. Proceedings of the 2nd International Conference on Technology and Educational Science (ICTES 2020), 540(ICTES 2020), 156-162. https://doi.org/https://dx.doi.org/10. 2991/assehr.k.210407.230

Maheswari, P. A. M., Adnyani, N. L. P.

Jurnal IImu Sosial dan Humaniora | 593 
S., \& Suwastini, N. K. A. (2020). Interlanguage Analysis on Indonesian EFL Learners' Compositions. Lingua Didaktika: Jurnal Bahasa Dan Pembelajaran Bahasa, 14(2), 121-131. https://doi.org/10.24036/ld.v14i2.1 08643

Mahmud, M. (2015). Language and Gender in English Language Teaching. TEFLIN Journal, 21(2), 172-185.

https://doi.org/10.15639/teflinjourn al.v21i2/172-185

Millett, K. (2000). Sexual politics. In Feminist Literary Criticism. University of Illinois Press. https://doi.org/10.4324/978131584 6163

Nasrullah. (2016). Gender's Visibility in Textbooks. Inovish Journal, 1(1), 40-55.

http://ejournal.polbeng.ac.id/index. php/lJ/article/download/15/15

Parker, R., Larkin, T., \& Cockburn, J. (2017). A visual analysis of gender bias in contemporary anatomy textbooks. Social Science and Medicine, 180, 106-113. https://doi.org/10.1016/j.socscimed .2017.03.032

Paudel, J., \& Khadka, P. (2019). Analysis of an English Textbook from a Feminist Perspective. International Journal of Humanities, Social Sciences and Education, 6(9), 10-21. https://doi.org/10.20431/23490381.0609002

Phillips, S. P. (2005). Defining and measuring gender-A social determinant of health whose time has come. International Journal for Equity in Health, 4(11), 1-4. https://doi.org/http://dx.doi.org/10.1 186/1475-9276-4-11

Purnamasari, N. M. G., Putra, I. N. A. J., \& Suwastini, N. K. A. (2016). A descriptive study on the use of code mixing by the English teacher at SMAN Bali Mandara in the academic year 2014/2015. Lingua Scientia, 23(2), 1-8. https://doi.org/http://dx.doi.org/10.2 3887/ls.v23i2.16070

Puspawati, N. W. N., Suwastini, N. K. A., Hutapea, J. V., Dantes, G. R., \& Adnyani, N. L. P. S. (2021). Consumption and production of short film: Toward the conceptualization of multimodal language learning for developing $6 \mathrm{Cs}$ skills in the digital age. Journal of Physics: Conference Series, 1810(1).

https://doi.org/10.1088/17426596/1810/1/012054

Rachmijati, C., \& Cahyati, S. S. (2018). Gender Representation in Textbook Bahasa Inggris Grade X. ELTIN JOURNAL, Journal of English Language Teaching in Indonesia, 6(2), 59. https://doi.org/10.22460/eltin.v6i2. p59-69

Sari, N. T. A. (2011). Visible Boys, Invisible Girls: the Representation of Gender. Indonesian Journal of Applied Linguistics, 1(1), 80-99. http://jurnal.upi.edu/file/07_Nadia_ Visible_Boys.pdf

Setyono, B. (2018). The Portrayal of Women in Nationally-Endorsed English as a Foreign Language

Jurnal IImu Sosial dan Humaniora | 594 
(EFL) Textbooks for Senior High School Students in Indonesia. Sexuality and Culture, 22(4), 10771093.

https://doi.org/10.1007/s12119018-9526-2

Shamsuddin, C. M., \& Hamid, B. A. (2017). Representational meanings of gender stereotyped professional occupation images in selected Malaysian English language textbooks. $3 \mathrm{~L}$ : Language, Linguistics, Literature, 23(4), 128142. https://doi.org/10.17576/3L2017-2304-10

Suhartono, S., \& Kristina, D. (2018). Gender Bias in Textbooks and Test Items of English Language Learning in the Indonesian Context. PRASASTI International Conference on Recent Linguistics Research, 166(Prasasti 2018), 425-428.

https://doi.org/10.2991/prasasti18.2018.78

Sulaimani, A. (2017). Gender Representation in EFL Textbooks in Saudi Arabia: A Fair Deal? English Language Teaching, 10(6), 44.

https://doi.org/10.5539/elt.v10n6p4 4

Sunderland, J. (2006). Language and gender: An advanced resource book. 37(02). https://doi.org/10.1017/s00474045 08080445

Suwastini, N. K. A. (2013). Perkembangan Feminisme Barat dari Abad Kedelapanbelas hingga Postfeminisme: Sebuah Kajian Teoretis. Jurnal IImu Sosial Dan
Humaniora.

Suwastini, N. K. A., Banjar, I. D. A. O. V. J., Tienty, L. P. C. A., Sasmita, I. M. D. G., \& Nitiasih, P. K. (2020). Rachel Chu as liberal feminist in Kevin Kwan's Crazy Rich Asians (2013). International Journal of Language and Literature, 4(3), 123-132.

Suwastini, N. K. A., Suprianti, G. A. P., \& Fitrianti, N. K. (2018). Are the women really strong? An analysis on the characterizations of the female main character in Murti Bunanta's "Seri Wanita Perkasa." In M. H. Santosa, I. M. S. Paramarta, N. L. P. S. Adnyani, \& I. G. A. L. P. Utami (Eds.), International Conference on English Across Culture (Vol. 4, pp. 108-119). Undiksha Press. https://doi.org/10.1002/jctb.500042 3502

Suwastini, N. K. A., Utami, I. A. I., \& Galla, E. W. (2018). The popular and the academic: performing analysis on Disney's Beauty and the Beast (2017). In M. H. Santosa, I. M. S. Paramarta, N. L. P. S. Adnyani, \& I. G. A. L. P. Utami (Eds.), Fourth International Conference on English Across Culture (Issue 4, pp. 47-57). Undiksha Press.

Suwastini, N. K. A., \& Yukti, W. G. S. (2017). Errors analysis in short biography text written by the 11th grade students of a vocational high school in Singaraja. International Journal of Language and Literature, 1(1), 1-10. https://ejournal.undiksha.ac.id/inde

Jurnal IImu Sosial dan Humaniora | 595 
x.php/IJLL/article/download/9612/6 116

Taylor, F. (2003). Content analysis and gender stereotypes in children's books. Teaching Sociology, 31(3), 300-311.

https://doi.org/10.2307/3211327

Tong, R. (2009). Feminist thought (Third Edit). Westview Press.

UNESCO. (2012). Gender mainstreaming in teacher education policy: A training module.

http://unesdoc.unesco.org/images/ 0022/002217/221707E.pdf

Utami, I. G. A. L. P., Suwastini, N. K. A., Artini, N. N., \& Kultsum, U. (2020). Values of character education in the characterizations of Dory in Disneys' animated feature Finding Dory (2016). International Conference on Innovative Research Across Disciplines (ICIRAD 2019), 394(ICIRAD 2019), 119-126.

https://doi.org/10.2991/assehr.k.20 0115.020

Widasuari, N. W. D., Suwastini, N. K. A., Wahyuni, L. G. E., \& Visestayati, N. P. A. (2020). Lucy Pevensie'S Characterizations in C.S. Lewis' Narnia: the Lion, the Witch, and the Wardrobe. International Journal of Language and Literature, 4(1), 47. https://doi.org/10.23887/ijll.v4i1.30 227

Wollstonecraft, M. (1976). A Vindication of the Rights of Woman. Dover Publication.

Yang, C. C. R. (2011). Gender representation in a Hong Kong primary English textbook series:
The relationship between language planning and social policy. Current Issues in Language Planning, 12(1), $\quad$ 77-88. https://doi.org/10.1080/14664208. 2011.541390

Yang, C. C. R. (2016). Are males and females still portrayed stereotypically? Visual analyses of gender in two Hong Kong primary English Language textbook seriest. Gender and Education, 28(5), 674-692. https://doi.org/10.1080/09540253. 2015.1103839

Yasin, M. S. M., Hamid, B. A., Othman, Z., Bakar, K. A., Hashim, F., \& Mohti, A. (2012). A Visual Analysis of a Malaysian English School Textbook: Gender Matters. Procedia - Social and Behavioral Sciences, 69(Iceepsy), 18711880.

https://doi.org/10.1016/j.sbspro.20 12.12.140

Yonata, F., Riau, K., Mujiyanto, Y., \& Semarang, U. N. (2017). The Representation of Gender in English Textbooks in Indonesia. Language Circle - Journal of Language and Literature, 12(1), 91-102.

https://doi.org/10.15294/lc.v12i1.1 1473 